\title{
Penggunaan Calcium Channel Blocker pada Tatalaksana Anestesi Clipping Aneurisma Otak
}

Fanda Ayyu Rindiati*), Himawan Sasongko ${ }^{* *}$, Moh Sofyan Harahap ${ }^{* *}$

${ }^{*}$ Peserta Didik Program Pendidikan Dokter Spesialis Anestesiologi dan Terapi Intensif, Fakultas Kedokteran Universitas Diponegoro - RSUP. Dr Kariadi Semarang, Staf Pengajar Program Pendidikan Dokter Spesialis Anestesiologi dan Terapi Intensif, Fakultas Kedokteran Universitas Diponegoro - RSUP. Dr Kariadi Semarang

\begin{abstract}
Abstrak
Perdarahan subarachnoid dapat diartikan sebagai proses pecahnya pembuluh darah di ruang yang berada dibawah arakhnoid (subarachnoid). Prevalensi terjadinya perdarahan subaraknoid dapat mencapai hingga 33.000 orang per tahun di Amerika Serikat. Penyebab paling sering perdarahan subarachnoid adalah ruptur aneurisma salah satu arteri di dasar otak dan adanya malformasi arteriovena (MAV). Pada umumnya aneurisma terjadi pada sekitar 5\% dari populasi orang dewasa, terutama pada wanita. Penanganan pada aneurisma pembuluh darah otak salah satunya dengan clipping aneurisma. Tindakan tersebut beresiko terjadi vasospasme serebral. Nimodipine adalah suatu calcium chanel blocker yang penting dalam pengelolaan operasi aneurisma karena mempunyai efek vasodilatasi pembuluh darah serebral dan termasuk dalam bagian dari manajemen vasospasme serebral. Pada laporan ini, dilaporkan dua kasus tindaan clipping aneurisma. Pasien pertama adalah wanita usia 69 tahun, berat badan $60 \mathrm{~kg}$ dengan diagnosa SAH hari ke 18 yang mengalami defisit neurologi berupa hemiparese dextra dan afasia motorik. Pasien kedua adalah wanita usia 57 tahun berat badan $60 \mathrm{~kg}$ dengan diagnosa SAH hari ke 20 dan mengalami defisit neurologi hemiparese kanan dan afasia sensorik. Pada kedua pasien dilakukan tindakan pembedahan kraniotomi clipping aneurisma. Kedua pasien memiliki hasil akhir yang baik. Akan tetapi, ada perbedaan lama perawatan antara pasien yang menjalani terapi awal nimodipine dan yang tidak menerima terapi tersebut.
\end{abstract}

Kata kunci: Calcium Channel Blocker; Clipping Aneurisma; Nimodipine; SAH; Vasospasme

JNI 2019; 8 (3): 202-06

\section{Administration of Calcium Channel Blocker in Anaesthesia Management of Cerebral Aneurysm Clipping}

\begin{abstract}
Subarachnoid hemorrhage can be interpreted as the process of rupture of blood vessels in the space under the arachnoid (subarachnoid). The prevalence of subarachnoid hemorrhage can reach up to 33,000 people per year in the United States. The most common causes of subarachnoid bleeding are ruptured aneurysm in one of the arteries at the base of the brain and the presence of arteriovenous malformations (MAV). In general, aneurysms occur in about $5 \%$ of the adult population, especially in women. Therapy in cerebral vascular aneurysms, one of which is clipping aneurysms. These actions are at risk of cerebral vasospasm. Nimodipine is a calcium channel blocker which is important in the management of aneurysm surgery because it has a vasodilating effect on cerebral vessels and is included in the management of cerebral vasospasm. In this report, two cases of clipping aneurysm are reported. The first patient was a woman aged 69 years, body weight $60 \mathrm{~kg}$ with a diagnosis of SAH day 18 who had a neurological deficit in the form of hemiparese dextra and motor aphasia. The second patient was a 57-yearold woman weighing $60 \mathrm{~kg}$ with a diagnosis of SAH day 20 and had a neurological deficit in the form of right hemiparese and sensory aphasia. In both patients, clipping aneurysm was performed by craniotomy surgery. Both patients had good results. However, there is a difference in the length of stay between patients who underwent initial nimodipine therapy and who did not receive it.
\end{abstract}

Key words: Clipping Aneurysm; Calcium Channel Blocker; Nimodipine; SAH; Vasospasm

JNI 2019; 8 (3): 202-06 


\section{Pendahuluan}

Perdarahan subaraknoid dapat diartikan sebagai proses pecahnya pembuluh darah di ruang yang berada dibawah arachnoid (subarachnoid). Prevalensi terjadinya perdarahan subaraknoid dapat mencapai hingga 33.000 orang per tahun di Amerika Serikat. Perdarahan subarachnoid memiliki puncak insidensi pada usia sekitar 55 tahun untuk laki-laki dan 60 tahun untuk perempuan. Lebih sering dijumpai pada perempuan dengan rasio 3:2. ${ }^{1}$ Penyebab paling sering perdarahan subarachnoid adalah ruptur aneurisma salah satu arteri di dasar otak dan adanya MAV. Beberapa jenis aneurisma yang dapat terbentuk di arteri otak antara lain seperti aneurisma sakuler (berry), Aneurisma fusiformis, dan Aneurisma mikotik. ${ }^{2}$

Vasospasme dan perdarahan ulang adalah komplikasi paling sering pada perdarahan subarachnoid. Tanda dan gejala vasospasme dapat berupa penurunan status mental dan defisit neurologis fokal. Vasospasme akan menyebabkan iskemia serebral yang tertunda dengan dua pola utama, yaitu infark kortikal tunggal dan lesi multipel luas. Perdarahan ulang mempunyai mortalitas $70 \%$. Untuk mengurangi risiko perdarahan ulang sebelum dilakukan perbaikan aneurisma, tekanan darah harus dikelola hati-hati dengan diberikan obat fenilefrin, norepinefrin, dan dopamine (untuk pasien dengan hipotensi), labetalol, esmolol, nikardipin (untuk pasien dengan hipertensi) dan nimodipine. ${ }^{1}$ Sekitar $10 \%$ penderita $\mathrm{SAH}$ meninggal sebelum tiba di RS dan $40 \%$ meninggal tanpa sempat membaik sejak awitan. Tingkat mortalitas pada tahun pertama sekitar $60 \%$. Apabila tidak ada komplikasi dalam 5 tahun pertama sekitar 70\%. Apabila tidak ada intervensi bedah maka sekitar $30 \%$ penderita meninggal dalam 2 hari pertama, $50 \%$ dalam 2 minggu pertama, dan $60 \%$ dalam 2 bulan pertama. ${ }^{1}$ Laporan Kasus ini membahas 2 pasien yang didiagnosa SAH serta dilakukan tindakan pembedahan kraniotomi clipping aneurisma. Dalam laporan kasus ini, akan dibahas peranan Nimodipine dalam pengelolaan pasien dan keluaran dari pasien yang dikelola.

\section{Kasus}

Pasien 1

Anamnesis

Pasien pertama perempuan usia 65 tahun datang pada 29 desember 2018 dengan keluhan utama nyeri di kepala dengan riwayat penyakit sekarang nyeri kepala yang dirasakan terus menerus sejak 1 tahun yang lalu disertai tidak bisa bicara (afasia). Pasien memiliki riwayat hipertensi.

\section{Pemeriksaan Fisik}

Pemeriksaan fisik yang didapat pada pasien pertama saat tiba di IGD, keadaan umum lemah, GCS E4M6Vafasia, dengan Tekanan darah 151/90 $\mathrm{mmHg}$, laju nadi 96x/menit, irama pernafasan $25 \mathrm{x} /$ menit, suhu tubuh 37,4 derajat celcius dan berat badan $80 \mathrm{~kg}$. Pemeriksaan fisik ekstremitas didapatkan kedua kaki bengkak dan kekuatan motorik superior dan inferior 4/4/4. Untuk Pemeriksaan lain yang tidak disebutkan diatas dalam batas normal.

\section{Pemeriksaan Penunjang}

Hasil Laboratorium yang didapatkan yaitu hasil darah rutin: $\mathrm{Hb}$ 11,2 $\mathrm{g} / \mathrm{dL}$, Hematokrit 33,4\%, Leukosit $8300 / \mu 1$, Trombosit 372000/ $\mu 1$. Hasil kimia klinik: Gula Darah Sewaktu $130 \mathrm{mg} / \mathrm{dL}$, ureum $19 \mathrm{mg} / \mathrm{dL}$, kreatinin 0,7 $\mathrm{U} / \mathrm{L}$, natrium $136 \mathrm{mmol} / \mathrm{L}$, kalium 4,7 $\mathrm{mmol} / \mathrm{L}$. Hasil studi koagulasi: Protrombin Time 12,0 kontrol 10,8, Activated Partial Thromboplastin Time 37,4 kontrol 31,1. Hasil Xray Thorax AP Kardiomegali LV, Pulmo tak tampak infiltrat. Gambaran aneurisma bentuk saccular pada arteri communicans poserior kanan dengan neck (ukuran 2,7 $\mathrm{mm}$ ) dan (diameter $\pm 3 \mathrm{~mm}$, panjang $2,7 \mathrm{~cm}$ ) ke arah inferior. Tak tampak ekstravasasi kontras perianeurisma. Stenosis parsial pada segmen cavernosa arteri carotis interna kanan. Infark lakunar pada crus anterior capsula interna kanan kiri dan crus posterior capsula interna kanan. Hypodensiti area pada pericornu anterior dan posterior ventrikel lateral kanan kiri, cenderung gambaran gliosis. (Gambar 1)

Pasien 2

Anamnesis 


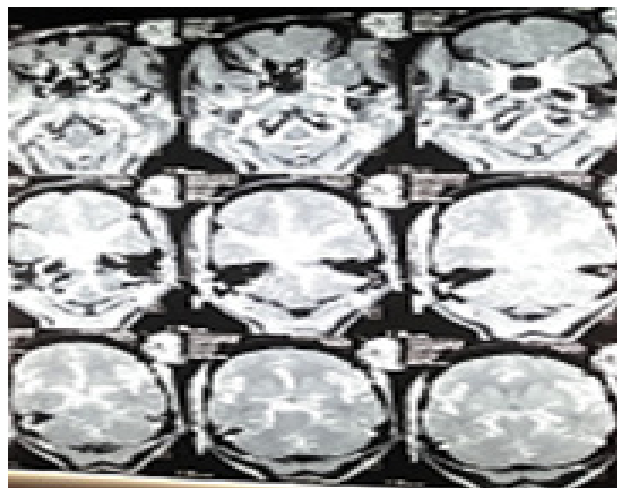

Gambar 1. Hasil MSCT Angiografi Kepala

Pasien kedua perempuan usia 69 tahun datang pada 12 Januari 2019 dengan keluhan penurunan kesadaran sejak 1 hari sebelum datang ke rumah sakit. Dari anamnesis dengan keluarga pasien, pasien memiliki riwayat hipertensi.

\section{Pemeriksaan Fisik}

BerdasarkankeadaanpasiensaatdiIGD, didapatkan keadaan umum lemah, GCS E2M4V2, tekanan darah 190/90 mmHg, laju nadi $120 \mathrm{x} /$ menit, laju pernafasan $28 \mathrm{x} /$ menit, suhu tubuh 37,2 derajat celcius dan berat badan $70 \mathrm{~kg}$. Pemeriksaan fisik paru didapat ronkhi kasar di kedua lapang paru, ekstremitas kaki bengkak dan tidak didapatkan kesan lateralisasi pada pemeriksaan motorik.

\section{Pemeriksaan Penunjang}

Hasil Laboratorium yang didapatkan yaitu hasil darah ruti: $\mathrm{Hb} 10,5 \mathrm{~g} / \mathrm{dL}$, Hematokrit 30,3\%, Leukosit 14300/ $\mu 1$, Trombosit 324000 / $\mu 1$. Hasil kimia klinik: gula darah sewaktu 197 $\mathrm{mg} / \mathrm{dL}$, ureum $28 \mathrm{mg} / \mathrm{dL}$, kreatinin $0,6 \mathrm{U} / \mathrm{L}$, natrium $133 \mathrm{mmol} / \mathrm{L}$, kalium $4,4 \mathrm{mmol} / \mathrm{L}$. Hasil studi koagulasi: protrombin time 12,6 kontrol 14,4, Activated Partial Thromboplastin Time 24,9 kontrol 30,5. Hasil Xray thorax AP Kardiomegali LV, pulmo tak tampak infiltrat. Gambaran aneurisma bentuk saccular pada arteri communicans posterior kiri dengan wide neck (ukuran $\pm 3,3 \mathrm{~mm}$ ) dan ( diameter $\pm 4,2$ $\mathrm{mm}$, panjang $8,0 \mathrm{~cm}$ ) ke arah inferior, yang mengalami rupture dan masih tampak perdarahan aktif saat ini. Subarachnoid haemorraghe disertai ventricular hemorage. Gambaran hidrosefalus communicans tampak tanda-tanda peningkatan TIK. (Gambar 2)

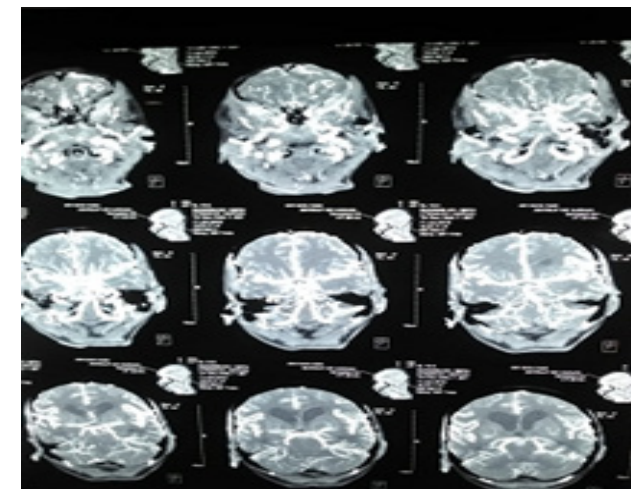

Gambar 2. Hasil MSCT Angiografi Kepala

Pengelolaan Anestesi

Pasien pertama diberikan premedikasi SA 0,25 mg. Kemudian diinduksi dengan Propofol 200 $\mathrm{mg}$, Fentanyl $100 \mathrm{mcg}$, dan rocuronium $50 \mathrm{mg}$. Pasien di maintenance dengan Propofol 30mg/ jam, rocuronium $3 \mathrm{mg} / \mathrm{jam}$, fentanyl $25 \mathrm{mcg} / \mathrm{jam}$, juga menggunakan agent sevoflurane 0,5 MAC.

Durante operasi, Vital sign selama operasi relative stabil dengan MAP rata rata 65 dengan menggunakan arteri line dan HR 60. Pasien diberikan Manitol $250 \mathrm{mg}$ sebagai neuroprotektor. Lama Operasi 260 menit. Total cairan masuk 3500 cc kristaloid. Perdarahan 100 cc. Jumlah Urine $1500 \mathrm{cc}$.

Pasien kedua diberikan premedikasi SA 0,25 mg. Kemudian diinduksi dengan Propofol 150 $\mathrm{mg}$, Fentanyl $100 \mathrm{mcg}$, dan rocuronium $40 \mathrm{mg}$. Pasien di maintenance dengan Propofol 30mg/ jam, rocuronium $3 \mathrm{mg} / \mathrm{jam}$, fentanyl $25 \mathrm{mcg} / \mathrm{jam}$, juga menggunakan agent sevoflurane 0,5 MAC. Durante operasi, Vital sign selama operasi relative stabil dengan MAP rata rata 65 diukur dengan arteri line dan HR 60. Pasien diberikan Manitol $250 \mathrm{mg}$ sebagai neuroprotektor. Lama Operasi 290 menit. Total cairan masuk 3500 cc kristaloid. Perdarahan 100 cc. Jumlah Urine 1540 cc.

\section{Pengelolaan Perioperatif}

Pasien pertama diberikan Nimodipin 2cc/jam selama 6 hari dilanjutkan Nimodipin tab $60 \mathrm{mg} /$ 6 jam preop, selain itu pasien juga diberikan Moxifloxacin $400 \mathrm{mg}$ iv/24 jam Amlodipin tab 10 $\mathrm{mg} / 24$ jam, Phenitoin $200 \mathrm{mg}$ iv/ 24 jam, ranitidin $50 \mathrm{mg}$ iv/12 jam, asam Tranexamat $1 \mathrm{gr} / 12 \mathrm{jam}$ untuk terapi supportif. 
Setelah operasi, pasien dirawat di ICU dan mendapat terapi Inj Nimotop $1,2 \mathrm{ml} / \mathrm{jam}$ via syiringe pump, Inj fentanyl $10 \mathrm{mcg} / \mathrm{jam}$ via syringe pump, Inj Parasetamol $1 \mathrm{gr} / 8$ jam, Inj Omeprazole $40 \mathrm{mg}$ / 12 jam,Inj Phenitoin $200 \mathrm{mg}$ $/ 24$ jam, Inj asam tranexamat $500 \mathrm{mg} / 8$ jam, Inj Vit K $10 \mathrm{mg} / 12$ jam dan amlodipin tab $5 \mathrm{mg} /$ 24 jam. Total hari perawatan pada pasien ini di ruang intensif adalah 42 hari. Pasien dipindahkan ke ruang biasa setelah 42 hari dirawat di ruang intensif tanpa tanda tanda perburukan atau munculnya gejala kelainan neurologis yang baru.

Untuk pasien kedua, terapi preop berupa nimodipin tab $60 \mathrm{mg} \mathrm{PO} / 12$ jam, phenitoin $200 \mathrm{mg}$ iv/24 jam, ranitidin $50 \mathrm{mg}$ iv/12 jam, levofloxacin $750 \mathrm{mg}$ iv/24 jam. Post op dirawat di HCU mendapat terapi amlodipin $10 \mathrm{mg} / 24$ jam, nebul ventolin pulmicord/8 jam, morfin 0,5 $\mathrm{mg} / \mathrm{jam}$ via syiringe pump, ketorolac $10 \mathrm{mg}$ iv/8 jam, paracetamol $1000 \mathrm{mg} \mathrm{PO} / 8 \mathrm{jam}$, inj ranitidin $50 \mathrm{mg}$ iv/12 jam. Total perawatan intensif pada pasien ini adalah 28 hari. Pasien dipindahkan ke ruang biasa setelah 28 hari dirawat di ruang intensif tanpa tanda tanda perburukan atau munculnya gejala kelainan neurologis yang baru.

\section{Pembahasan}

Pada kedua pasien mendapat terapi nimodipin sebelum operasi. kedua pasien tidak mengalami perburukan dan tidak didapatkan tanda tanda dan gejala terjadinya vasospasme serebral baik sebelum, durante op, atau setelah operasi saat dirawat di ruang intensif. Penelitian sebelumnya menunjukkan bahwa terapi terapi nimodipin menurunkan secara signifikan infark serebral. Hasil ini dicerminkan oleh hasil yang jauh lebih baik setelah 6 bulan dibandingkan dengan kontrol pada sebuah penelitian, juga didapatkan data bahwa tidak ada pasien yang berada dalam kondisi vegetative. ${ }^{3}$ Faktor-faktor perantara di mana nimodipine memberikan efek menguntungkan diantaranya adalah tentang mekanisme yang memungkinkan nimodipine memberikan efek neuroprotektif langsung yang diinduksi oleh pencegahan serangan radikal bebas pada mitokondria intraneuronal,
peningkatanReaktivitas $\mathrm{CO}_{2}$ dan metabolisme oksigen otak, atau pengurangan kerusakan jaringan yang disebabkan oleh kalsium overload pada reperfusi. ${ }^{4}$ Pada studi lain menunjukkan bahwa Delayed Cerebral Ischemic ditemukan menurun pada pasien dengan kombinasi nimodipine IV selama 10 hari diikuti dengan oral selama 11 hari., ${ }^{5,6}$ Patofisiologi Delayed Cerebral Iskemik setelah SAH dari studi hewan menunjukkan hal itu sejak awal cedera otak setelah SAH menunjukkan vasospasme kemudian terjadi hipoksia, yang memicu kaskade apoptosis. Kaskade inidisebabkan oleh proses peradangan dan mengangkat $\mathrm{Ca}_{2}+$-protein kinase mitogenaktif teraktivasi, termasuk ERK1/2,p38, dan JNK, yang menyebabkan kematian neuron dan DCI. Oleh karena itu, perbaikan awal hipoksia dengan meningkatkan aliran darah otak atau mengurangi vasospasme dengan nimodipine dapat berkontribusi untuk mengurangi cedera otak dan melindungi neuron. ${ }^{7,8}$ Karena itu, perawatan dini dengan IV nimodipine mungkin berpotensi mengurangi kejadian vasospasme setelah SAH dan mengurangi kejadian Delayed Cerebral Iskemik. ${ }^{9,10}$ Dalam kasus ini, pemberian nimodipin oral berhasil mencegah terjadinya vasospasme serebral ditunjukkan dengan tanda tidak ada perburukan pasien dan tidak didapatkan adanya defisit neurologis pada saat perawatan di ruang intensif.

\section{Simpulan}

Penggunaan nimodipin sebagai calcium channel blocker dapat digunakan untuk mencegah terjadinya komplikasi serebral pada pasien aneurisme otak yang akan menjalani maupun setelah menjalani proses kliping aneurisma. Komplikasi yang timbul pasca terapi seperi vasospasme serebral, delayed cerebral ischemic, dan lain lain dapat dikurangi angka kejadiannya. Dengan berkurangnya komplikasi yang disebut diatas, dapat mengurangi morbiditas dan mortalitas pasien yang dirawat di ruang intensif.

\section{Daftar Pustaka}

1. Setyopranoto I. Penatalaksanaan Pendarahan 
Subarakhnoid. Contin Med Educ. 2012, 39; 807-811.

2. Mathias B, Frotscher M. Diagnosis topik neurologi duus: anatomi, fisiologi, tanda, gejala. Jakarta: Penerbit Buku Kedokteran EGC. 2010.

3. Bele S, Proescholdt MA, Hochreiter A, Schuierer G, Scheitzach J, Wendl C, et al. Continuous intra-arterial nimodipine infusion in patients with severe refractory cerebral vasospasm after aneurysmal subarachnoid hemorrhage: a feasibility study and outcome results. Acta Neurochir (Wien). 2015, 157; 2041-50.

4. Biondi A, Ricciardi GK, Puybasset L, Abdennour L, Longo M, Chiras J, et al. Intra-arterial nimodipine for the treatment of symptomatic cerebral vasospasm after aneurysmal subarachnoid hemorrhage: preliminary results. Am J Neuroradiol. 2004, $25 ; 1067-76$.

5. Karinen $\mathrm{P}$, Koivukangas $\mathrm{P}$, Öhinmaa A, Koivukangas J, Ohman J. Cost-effectiveness analysis of nimodipine treatment after aneurysmal subarachnoid hemorrhage and surgery. Neurosurgery. 1999;45:780-85.
6. Wolf S, Martin H, Landscheidt JF, Rodiek SO, Schürer L, Lumenta CB. Continuous selective intraarterial infusion of nimodipine for therapy of refractory cerebral vasospasm. Neurocrit Care. 2010, 12; 346-51.

7. Ott S, Jedlicka S, Wolf S, Peter M, Pudenz $\mathrm{C}$, Merker $\mathrm{P}$, et al. Continuous selective intra-arterial application of nimodipine in refractory cerebral vasospasm due to aneurysmal subarachnoid hemorrhage. BioMed Res Int. 2014.

8. Pickard JD, Murray GD, Illingworth R, Shaw MD, Teasdale GM, Foy PM, et al. Effect of oral nimodipine on cerebral infarction and outcome after subarachnoid haemorrhage: British aneurysm nimodipine trial. Bmj. 1989, 298; 636-42.

9. Samseethong T, Suansanae T, Veerasarn K, Liengudom A, Suthisisang C. Impact of Early Versus Late Intravenous Followed by Oral Nimodipine Treatment on the Occurrence of Delayed Cerebral Ischemia Among Patients With Aneurysm Subarachnoid Hemorrhage. Ann Pharmacother. 2018, 52;1061-69.

10. Wainsztein N, Lucci FR. Cortical spreading depression and ischemia in neurocritical patients. Neurol Clin. 2017, 35;655-664 